\author{
ARTIGO \\ dO https://doi.org/10.22481/praxisedu.v16i37.6433
}

\title{
MUSIC COMPUTER TECHNOLOGIES AS AN INTEGRATIVE NETWORKING EDUCATIONAL ENVIRONMENT
}

\author{
TECNOLOGÍAS DE LA COMPUTADORA MUSICAL COMO ENTORNO \\ INTERACTIVO DE REDES INTERACTIVAS
}

\section{TECNOLOGIAS DE COMPUTADORES DE MÚSICA COMO AMBIENTE EDUCACIONAL EM REDE INTERATIVA}

\author{
I.B. Gorbunova \\ Herzen State Pedagogical University - Russia
}

K.J. Plotnikov

Herzen State Pedagogical University - Russia

H. Hiner

Music Vision International - Estados Unidos

\begin{abstract}
The study is made relevant by the search for the most appropriate approaches to the pedagogical development of information technology's new features, applicable to interactive music teaching - for example, teaching to play a musical instrument with the use of a computer program. The aim of the study is to consider interactivity, network interaction, and the implementation of educational functions as key features of music computer technologies (MCT). These technologies can help develop an effective methodology for appropriate training and new soft- and hardware systems with which students can learn three of the most important components of musical skill: the keyboard of a particular instrument, musical notation, and musical theory. The authors conclude that MCT can and should act as an interactive networking educational environment, and it is necessary to prepare a repertoire list for the educational process in such conditions, as well as to search for legal organizational forms of this activity.
\end{abstract}

Keywords: interactive communication, information technologies (IT), teaching methods, music computer technologies (MCT), educational environment, teaching music, technology in education

Resumen: El estudio se hace relevante mediante la búsqueda de los enfoques más apropiados para el desarrollo pedagógico de las nuevas características de la tecnología de la información, aplicables a la enseñanza musical interactiva, por ejemplo, enseñar a tocar un instrumento musical con el uso de un programa informático. El objetivo del estudio es considerar la interactividad, la interacción de la red y la implementación de funciones educativas como características clave de las tecnologías informáticas de música (MCT). Estas tecnologías pueden ayudar a desarrollar una metodología efectiva para la capacitación adecuada y los nuevos sistemas de software y hardware con los cuales los estudiantes 
pueden aprender tres de los componentes más importantes de la habilidad musical: el teclado de un instrumento en particular, la notación musical y la teoría musical. Los autores concluyen que MCT puede y debe actuar como un entorno educativo interactivo en red, y es necesario preparar una lista de repertorio para el proceso educativo en tales condiciones, así como buscar formas organizativas legales de esta actividad.

Palabras clave: comunicación interactiva, tecnologías de la información (TI), métodos de enseñanza, tecnologías informáticas de música (MCT), entorno educativo, enseñanza de música, tecnología en educación.imperativo moral, universidad, humanidades.

Resumo: O estudo se torna relevante pela busca das abordagens mais apropriadas para o desenvolvimento pedagógico dos novos recursos da tecnologia da informação, aplicáveis ao ensino interativo de música - por exemplo, ensinar a tocar um instrumento musical com o uso de um programa de computador. O objetivo do estudo é considerar a interatividade, a interação em rede e a implementação de funções educacionais como principais recursos das tecnologias de computador da música (MCT). Essas tecnologias podem ajudar a desenvolver uma metodologia eficaz para treinamento apropriado e novos sistemas de software e hardware com os quais os alunos podem aprender três dos componentes mais importantes da habilidade musical: o teclado de um instrumento específico, notação musical e teoria musical. Os autores concluem que o MCT pode e deve atuar como um ambiente educacional de rede interativa, e é necessário preparar uma lista de repertórios para o processo educacional nessas condições, bem como buscar formas organizacionais legais dessa atividade.

Palavras-chave: comunicação interativa, tecnologias da informação (TI), métodos de ensino, tecnologias da música para computadores (MCT), ambiente educacional, ensino da música, tecnologia na educação

\section{INTRODUCTION}

The study uses the method of complex phenomenal analysis and the methodology of implicitly presented conclusions that music computer technologies (MCT) can help develop an effective methodology for appropriate training and new soft- and hardware systems, with which students learn three of the most important components of musical skill: the keyboard of a particular instrument, musical notation, and musical theory. The choice of this method was due to the multidisciplinarity of the phenomenon of MCT as a new high-tech educational creative environment.

MCT can and should act as an interactive networking educational environment, but the authors think it is necessary to prepare a repertoire list for the educational process in such conditions and conduct a search for legal organizational forms of this activity. 


\section{LITERATURE REVIEW}

The first music computer technologies (MCT) began to appear nearly 20 years ago. Due to its continuous development, today, these technologies have a wide range of capabilities [1]. However, despite its widespread use across the globe, the terminology in foreign literature is somewhat different from Russian, and in the authors' opinion, reflects the essence of this phenomenon less accurately. Various authors tend to use the following terms to describe MCT: music technology (D.B. Williams \& P.R. Webster [2] and others), digital technology or digital music technology (R. Crawford, 2007 [3] and others), and computerbased technology (P. Webster, 2002 [4] and others).

We can state that various aspects of the practical application of MCT may interest the following professional groups:

Professional musicians and other people working in the field of art. For example, MCT can be used as a creative laboratory of a composer and musician-programmer (from the method of J. Ksenakis to the works of E. Artemiev \& G. Belov, and the developments of S. Chibiryov [5]); as an analytical apparatus of an art critic, musicologist, cyberneticist (from the E. Kurs and M. Ignatiev's point of view to the research of I. Gorbunova and M. Zalivadnyi [6]), and culturologist (the research of L. Romanenko, the project of I. Alieva, I. Gorbunova \& S. Mezentseva [7]).

People working with sound-recording and sound-reproducing equipment—sound producers, sound engineers, performance group managers, and their assistants (from the practical developments to the implementation of this field of MCT by students in the WorldSkills Junior project).

Teachers working in general, additional, and inclusive education [e.g., 8-9], as well as prevocational and vocational education, including higher music and pedagogic education [10].

Music as a whole has the highest, irreplaceable purpose. It is a diversified field of creativity, a "living" repository of universal and national cultures; it is a language and a means of communication. With the development of MCT, we've discovered new ways of interacting with music (including musical material and musical instruments). There's no denying that the most important group interacting with MCT comprises children (adolescents, youth). Consequently, teaching methodology should be developed on the basis of their age-related 
capabilities and peculiarities; the software and hardware for MCT should be developed and adjusted on the basis of compatibility, optimal educational effect, etc.

According to the authors, the most relevant problem in the field of MCT application in general education (including pre-vocational education) resides in the unity of two components:

It is necessary to develop such a software and hardware base, with which the advantages of MCT will be maximized and the disadvantages will be minimized or easily eliminated.

It is necessary to develop an effective and accurate methodology for a student's mastery of MCT (with consideration of the particularities of students' specific categories).

In this regard, a question arises about the MCT features that can be the basis for solving this problem and that can act as key features.

\section{MATERIALS AND METHODS}

The authors of the article propose to consider the interactivity of students learning music in a networking educational environment as a fundamental characteristic of MCT, which is a specific manifestation of IT [11].

Interactivity (not to be confused with the manifestation of this principle in a different context [12]) includes a wide range of software and hardware systems that can be represented in the form of computer application programs for smartphones, tablets, desktop computers, etc [29]. To consider interactivity in the context of this work, we limit our attention to developments designed for teaching and playing a musical instrument.

By limiting the scope of consideration, we are able to focus on the nature of student interaction by means of MCT with the instrument and musical material (e.g., musical notations and various sound parameters, such as volume, register, timbre, musical texture, etc.). MCT can be used at all three levels of music education-technological, artistic, and pedagogical. This feature distinguishes MCT them from the musical education tools of previous eras.

Considering the question posed within the framework of the indicated problem and because of limitations on article length, we give a brief overview of the historical aspects of the use of MCT in the educational creative process. 
The methodology of implicitly presented conclusions, based on the most typical examples, is used in the article due to two factors:

the multidisciplinary nature of the MCT phenomenon, which spans many fields of studies, such as art, information science, pedagogics, and psychology, and

the format of the article.

Endogenous factors, similar to the time perspective factor (which is significant to the age group of subjects in the marshmallow experiment by Walter Mischel), as well as other individual psychological features, are minimized.

The article uses the following materials for analysis:

user market statistics for products included in the category of MCT (e.g., [13] and other materials from this and other IT industry websites)

general and particular features of specific versions of software and hardware systems that allow students to interact with the educational environment with maximum efficiency (e.g., [14])

results of previous research described in scientific articles from the Scopus database, Web of Science, and Russian scientific journals with relevant expertise that are included in the list of the Higher Attestation Commission of the Russian Federation (e.g., [15-16], etc.).

results of pedagogical observations, including the observations made during the development and implementation of methods for mastering MCT tools, presented during international research-to-practice conferences such as Modern Music Education, which is organized and arranged by the Herzen State Pedagogical University and the RimskyKorsakov St. Petersburg State Conservatory, and others.

\section{RESULTS}

Long-term observations and statistics indicate the following:

The IT industry is one of the leading sectors of the modern economy, despite the fact that the assessment of its achievements contains extreme poles, from hopes for positive changes to apocalyptic forecasts. Mobile communication tools and equipment, including smartphones and various sound devices, are getting cheaper every day, and their functionality and other features are constantly evolving and improving [17, 28].

The user IT market, including MCT, is subject to continuous rotation. 
Different models and versions of soft- and hardware are constantly replacing older versions; some soft- and hardware companies stay viable for a long time, while others disappear;

In the field of MCT under consideration, important and promising developments are the ones that use the achievements and advantages of these technologies to allow for student's interaction with three space-time elements of music at once:

a) a musical notation, which can be transferred from paper to screen

b) a keyboard of a musical instrument, as well as all other tools, including pedals and various buttons and switches (work with these tools can be performed both in real time and during preparation)

c) sound, which is a reflection of the auditory representations of an artistic image (including the one enclosed in a musical notation), and the result of accumulated experience in using the technical tools of a particular musical instrument

At the present time, there are many soft- and hardware configurations that use piano, accordion, saxophone, and guitar keyboard systems, including those made by Yamaha, Roland, Casio, etc.

Musical language became written about a thousand years ago, and its significant evolution took place in Russia, where the traditions of classical music education have been developing for many centuries. The beginnings of these traditions lie in home music education, as well as the theatrical work, of the nobles. Later, it developed into a system that began with children's music schools, which today are being transformed into a state network of additional education for children.

The way to fully comprehend the richness and diversity of musical culture in the learning process is also associated with the need to study musical notation and musical theory. This is evidenced by pedagogical observations, which include the experience of parents whose children learn to play a musical instrument in a children's music school or studio or with a private teacher. The complexity and multitasking of the learning process involve simultaneous execution of three actions at once:
a) seeing and deciphering notes,
b) reading and playing music (more often than not, the experience of playing one instrument is not applicable to another instrument), and
c) monitoring compliance with musical rules by ear. 
In the past, these complex tasks made music education either exclusive, for those who, despite challenges, were able to pay for many hours of classes and not lose their natural craving for music, or somewhat flawed, for those very rare people who were able to learn playing a musical instrument without the knowledge of theory.

Students (as well as their parents and teacher) can be satisfied with the artistic result of mastering a musical instrument only when they overcome obstacles in the musical technique (with the development of fine (finger) and gross (wrist) motor skills, absence and/or elimination of tightness of the shoulder girdle, etc.) and reach a certain level of fluency in reading music (or memorize a specific piece of music by heart).

In his work, M. Liu et al. [19, p. 253] suggests that during the consideration of the technology's use, one should always ask some basic questions: firstly, does this technology do something that I am not capable of doing without it? Secondly, does this technology perform the task easier, faster, and with the same or greater accuracy? Thirdly, is it possible to implement this technology? If the answer to all three questions is positive, then this technology should be implemented. We believe that this approach can serve as a methodological epigraph for many studies in the field of digital pedagogy [18].

\section{DISCUSSION}

Causal relationships of the mental reaction and the emotional state of a person have the properties of reversibility with the accumulation of life experience, which includes the skills of reflection and self-management. Using the Losada ratio [20] of 3:1, applicable both to social relations and to the people's attitude towards their activity, we can draw conclusions about the need to build such a teaching regime and apply such teaching methods, with which the ratio of successful attempts to difficulties will not go beyond the zone of 3-7:1.

Such ratio is achievable under the following conditions:

The presence of high initial individual indicators associated with morphogenetic features of the structure and development of certain functional areas of the human brain [21] (it is worth mentioning the proven and recognized by scientists advantages of practicing musical activities, which consist, firstly, in a special level of emotional coloring, secondly, in the possibility of using the sublimation mechanism, and thirdly, in addressing three modalities at once-visual, auditory and tactile-muscular complex of reactions [22]). 
Development and competent use of such a methodological system that is able to consider the individual preferences, limitations and potential of a student to the fullest extent (after all, the only mode of learning music that brings the most results is an individual lesson).

The use of tools that are able to translate the complexity of the learning process into creativity, allow to interact with all three components of music (sound, notation, and keyboard).

The Soft Way to Mozart program (developed by one the authors of the article, E. Heiner) is one of the attempts to create an educational system based on the principle of interactivity. With the help of the Educational and Methodical Laboratory "Music Computer Technologies" of the Russian Herzen State Pedagogical University, this program was included in the undergraduate and graduate courses, continuing education and professional retraining courses [23].

The promising outlook of this approach is evidenced by the following:

High demand for the course in different countries of the world, including Australia, the United Kingdom, Israel, Kazakhstan, Cuba, Mexico, Netherlands, Peru, Poland, Russia, Singapore, Turkey, the United States, and Chile.

Positive feedback from professional musicians, music teachers, students, and their relatives and friends (e.g., [27]).

The possibility of a comprehensive implementation of the principle of interaction with musical text and keyboard: the music text can be linked to the keyboard (in the context of this program, to the piano), and when a student plays music by reading notes from the screen, a computer program can analyze it and respond (with auditory feedback).

By fully implementing the principles of interactivity in the process of learning to play musical instruments using software and hardware systems [24], music computer technologies have ceased to be a dream and have become a reality - an activity carried out through organizational guidance and in the form of home music education (which is very important for the development of children's brains and thus the creative development of youth). Such musical education will undoubtedly contribute to strengthening ties between generations, becoming a modern (and so scarce at present) means of cultural leisure and giving young people sustainable guidelines in life for development of an artistic taste.

It should be noted that this practice can be distributed regardless of the social status of a particular family. 
The pedagogical and parent communities evaluate the scale and pace of IT expansion differently, but they agree on the following:

a) despite the continuous changes in the interfaces of application programs, addition/exclusion of various options, etc., students continue to successfully master MCT (and other IT),

b) it is rather difficult for one specialist (scientist or teacher) to objectively evaluate the educational effect of new technologies and analyze the measure of success of a technique that is being developed on the fly.

In this context, the use of networking interaction of participants in educational activities should be recognized as optimal. In this case, MCT function as an interactive networking educational environment, which is able to unite the subjects of educational activities related to learning a musical instrument. These subjects include the students that explore the tools of MCT (alone or with a parent or teacher) and teachers, who become an alternative for bogus tutors that put online inadequate video-lessons and advices, which can be useful in some cases but useless or even harmful in others.

It is very important to add another aspect of the identified problem-a repertoire (which is formed on the basis of principles [25, 26]). Since the mastering of any musical instrument and music teaching takes place on the examples of specific musical works, a repertoire is one of the decisive factors in the development of teaching methods using an interactive networking educational environment.

In Russia, a well-thought-out repertoire list (which is also applicable to other national education systems) eliminates the contradiction between computer and methodological developments based on the generally recognized achievements of the Russian classical music school and classical music education, and experience that is extremely poorly represented not only in the world but also in our own country.

\section{CONCLUSIONS}

1) At the present stage of their development (technological and pedagogical support), music computer technologies can and should act as an interactive networking educational environment in the sector of teaching a musical instrument.

2) Such an environment provides an opportunity for the teacher and student to interact with computer graphics and with a virtual or real keyboard (for the first time since the 
creation of musical notation, when none of the existing approaches in teaching musical literacy and other elements of music has allowed to connect all three elements into one).

3) The development of a teaching method for playing a musical instrument in an interactive networking educational environment can help solve a number of issues:

Determination of organizational forms of this educational process (this problem is intertwined with the issue of intellectual property regulation, legal status of participants interacting in such a network).

Repertoire formation.

Development and adjustment of soft- and hardware systems, with consideration for pedagogical and musical assessment (and forecast).

\section{REFERENCES}

1. Gorbunova I.B. Music Computer Phenomenon as New Educational Creative Environment // Izvestia: Herzen University Journal of Humanities \& Sciences. 2004. 4 (9). Pp. 123-138.

2. Experiencing music technology: software, data, and hardware. Edit. D. Williams, P. Webster. 2nd ed. NY: Schirmer Books, 1999. 693 p.

3. Crawford R. (2007) Authentic Learning and Digital Technology in the Music Classroom. Victoria: Monash University [Unpublished PhD dissertation] https://trove.nla.gov.au/work/35149324?q\&versionId=43654170.

4. Webster P. Computer-based technology and music teaching and learning. The new handbook of research on music teaching and learning. R. Colwell \& C. Richardson (Eds.), NY: Oxford University Press, 2002. pp. 416-439.

https://ru.scribd.com/document/382434165/The-New-Handbook-of-Research-onMusic-Teaching-and-Learning-a-Project-of-the-Music-Educators-NationalConference.

5. Gorbunova I. B., Chibirev S. V. (2019) Modeling the process of musical creativity. Opción, Año 35, Especial No. 22, pp. 392-409.

6. Gorbunova I. B., Zalivadny M. S. (2018) The Integrative Model for the Semantic Space of Music: Perspectives of Unifying Musicology and Musical Education // Problems of Music Science / Music Scholarship. № 4 (33). pp. 55-64. DOI: 10.17674/1997-0854.2018.4.055-064 
7. Alieva I.G., Gorbunova I.B., Mezentseva S.V. Music Computer Technologies as Means of Broadcasting and Preserving Musical Folklore (as exemplified by the Russian Far East) // Issues of the Musical Science/ Music Scholarship. 2019.1 (34). Pp. 140-149. DOI: 10.17674/1997-0854.2019.1.140-149

8. Jacko V. A., Choi J. Ho, Carballo A., Charlson Br., Moore J. E (2015) A New Synthesis of Sound and Tactile Music Code Instruction in a Pilot Online Braille Music Curriculum. Journal of Visual Impairment \& Blindness, pp. 153-157. DOI:10.1177/0145482x1510900212.

9. Gorbunova I. B., Govorova A. A. (2018) Music Computer Technologies in Informatics and Music Studies at Schools for Children with Deep Visual Impairments: from the Experience. In: Pozdniakov S., Dagienė V. (eds) Informatics in Schools. Fundamentals of Computer Science and Software Engineering. ISSEP 2018. Lecture Notes in Computer Science, vol. 11169. Springer, Cham DOI: https://doi.org/10.1007/978-3-030-02750-629.

10. Gorbunova I.B. Music Computer Technologies in the Perspective of Digital Humanities, Arts, and Researches. Opcion. 2019. T. 35. № S24, pp. 360-375.

11. Odinets V.P. Sketches on the History of Computer Science: a Study Guide in 3 vol. Vol. 3 // Syktyvkar: Komi Pedagogical Institute, 2013. Pp. 148.

12. Stensæth K. (2018) Music therapy and interactive musical media in the future: Reflections on the subject-object interaction. Nordic Journal of Music Therapy, Vol. 27 No. 4, pp. 312-327, DOI: 10.1080/08098131.2018.1439085.

13. Rating of Smartphone Manufacturers in 2019. [E-source] // https://www.itrew.ru. 14. Music Vision International LLC [E-source] // http://www.softmozart.com.

15. Petrovic-Dzerdz M., Trépanier A. (2018). Online Hunting, Gathering and Sharing - A Return to Experiential Learning in a Digital Age. The International Review of Research in Open and Distributed Learning, 19 (2). https://doi.org/10.19173/irrodl.v19i2.3732.

16. Calderón-Garrido D., Cisneros P., García I. D., Fernández D., de las Heras-Fernández R. (2019). La tecnología digital en la Educación Musical: una revisión de la literatura científica. Revista Electró-nica Complutense de Investigación en Educación Musical, No. 16, pp. 43-55. DOI: https://doi.org/10.5209/reciem.60768.

17. A. Karabanova et al. Age-Psychological and Psychological-Pedagogical Approaches to Ensuring Children's Information Security // [E-source] // Federal Service for 
Supervision of Communications, Information Technology and Mass Media's website // Available at: http://rkn.gov.ru/mass-communications/p700/p701/?print=1 / Section 9 (Access date: 12.12.2019).

18. Bauer W. I., Music Learning Today: Digital Pedagogy for Creating, Performing, and Responding to Music. Published to Oxford Scholarship Online: 2014. DOI:10,1093/acprof:oco/9780199890590.001.0001.

19. Liu M., Su S., Liu S., Harron J., Fickert C., Sherman B. (2016). Exploring 3D immersive and interactive technology for designing educational learning experiences. In Neto, de Souza R., Gomes A. S. (Eds.), Handbook of research on 3-D virtual environments and hypermedia for ubiquitous learning. Hershey, PA: IGI Global. (pp. 243-259). DOI: 10.4018 / 978-1-5225-5469-1.ch051.

20. Losada M., Heaphy E. (2004) The role of positivity and connectivity in the performance of business teams. American behavioral scientist, Vol. 47, No. 6, pp. 740-765.

21. Hernandez-Ruiz E. (2019) How is music processed? Tentative answers from cognitive neuroscience. Nordic Journal of Music Therapy, Vol. 28, No. 4, pp. 315-332, DOI: 10.1080/08098131.2019.1587785.

22. Schüler A. (2019) The Integration of Information in a Digital, Multi-modal Learning Environment. Learning and Instruction, Vol. 59, pp. 76-87. https://doi.org/10.1016/j.learninstruc.2017.12.005.

23. Gorbunova I. B., Hiner H. (2018) Music Computer Technologies and Interactive Systems of Education in Digital Age School. Proceedings of the International Conference Communicative Strategies of Information Society (CSIS 2018). Advances in Social Science, Education and Humanities Research. https://doi.org/10.2991/csis$\underline{18.2019 .25}$.

24. Cremata R., Powell B. (2016) Digitally mediated keyboard learning: Speed of mastery, level of retention and student perspectives. Journal of Music, Technology \& Education, Vol. 9, No. 2, pp. 145-159 (15). DOI: https://doi.org/10.1386/jmte.9.2.145_1

25. Plotnikov K. J. The Significance of the Artistic Repertoire for Teaching Music in a General Education School and for the Educational Process in General // Scientific research in the field of culture and education: issues and prospects. 1 // Collection of scientific articles based on the materials of the I International Conference of Young 
Scientists "Relevant Problems of Modern Culture and Education," March 29-31, 2016

// Under the scientific editorship of Olesina E.P. and Przhlenskaya I.B. Moscow:

Institute of Art Education and Cultural Studies of the Russian Academy of Education. 2016. Pp. 73-79.

26. Gorbunova I.B., Plotnikov K.Yu. Music-Related Educational Project for

Contemporary General Music Education of Schoolchildren. International Journal of Innovation, Creativity and Change. Vol. 9, Issue 13, 2019, pp. 683-699.

27. Materials about Soft Way to Mozart system from the XIII International Academic/Practical Conference. https://www.musiceducation2.org/pages/soft-way-tomozart-science-old, https://www.softmozart.com

28. Al-Shaher M.A. Assessment of M-Service Acceptance in Educational Context. Journal of Southwest Jiaotong University. Vol. 54, Issue 5, 2019, http://jsju.org/index.php/journal/article/view/369

29. Alasmri M., Onn W.C., Hin H.S. Social Networking Framework for Learning Motivation. Journal of Southwest Jiaotong University. Vol. 54, Issue 6, 2019, http://jsju.org/index.php/journal/article/view/450

\section{SOBRE OS AUTORES:}

\section{I.B. Gorbunova}

Full Professor, Doctor of Sciences (Pedagogy), Herzen State Pedagogical University of Russia, St.Petersburg, Russia. Email: gorbunova7575@ yandex.ru

(iD) http://orcid.org/0000-0003-4389-6719

\section{K.J. Plotnikov}

Senior Researcher, Ph.D. in Pedagogy, Herzen State Pedagogical University of Russia, St.Petersburg, Russia. Email: k.j.plotnikov@yandex.ru

iD http://orcid.org/0000-0001-8549-4262

\section{H. Hiner}

Musicologist, Director of the Music Vision International, Houston, TX, USA

Email: h.hiner@yandex.ru

(iD http://orcid.org/0000-0003-3093-4616

Recebido em: 17 de novembro de 2019 Aprovado em: 19 de dezembro de 2019

Publicado em: 30 de março de 2020 